\title{
A Study of Waterproof Reinforcement Layers for the Post-Cracking Behavior of Fiber Reinforced Concrete
}

\author{
Jung-Il Kim ${ }^{1}$, Min-Ho Gong ${ }^{2}$, Je-Young Song ${ }^{3}$, Sang-Keun $\mathrm{Oh}^{4}{ }^{4}$ and Byoungil Kim ${ }^{4, * \mathbb{C}}$ \\ 1 GCP KOREA INC., 301 Cheongneung-daero Namdong-gu, Incheon 21633, Korea; ji.kim@gcpat.com \\ 2 Hyundai Engineering CO., LTD., 232 Yulgok-ro75, Jongno-gu, Seoul 03058, Korea; gong92@hec.co.kr \\ 3 BK Waterproofing Technology Research Center, 232 Gongneung-ro, Nowon-gu, Seoul 01811, Korea; \\ jeyoung414@hanmail.net \\ 4 School of Architecture, Seoul National University of Science \& Technology, 232 Gongneung-ro, Nowon-gu, \\ Seoul 01811, Korea; ohsang@seoultech.ac.kr \\ * Correspondence: bikim@seoultech.ac.kr; Tel./Fax: +82-2-970-6512
}

Received: 12 July 2020; Accepted: 17 August 2020; Published: 20 August 2020

check for updates

Featured Application: The reduction and prevention of multiple cracks and leakage of water due to factory floor sinking.

\begin{abstract}
In this study, in order to protect the concrete layer from slab sinking cracks in the factory floor layer, four types of reinforcing materials with a notable waterproof performance are fixed at the bottom. Furthermore, short fibers mixed with concrete in order to evaluate the load transfer mechanism and residual stress retention ability are used. The change in flexural strength due to the waterproof reinforcement varied from about 10 to $48 \%$ depending on the type of reinforcing material, and the flexural strength of the specimen reinforced with Typar and Preprufe was demonstrated to be the best. Additionally, the increase in flexural strength due to the combination of the SF20 + Typar and MF2.8 + Preprufe specimens was remarkable. After the concrete matrix cracking, the toughness resulting from the fiber pull-out resistance and the increase in the reaction force of the waterproof reinforcement showed a marked improvement in all the test specimens. The test specimen reinforced with Typar demonstrated the best crack resistance regardless of the fiber type. The crack transfer mechanism in the concrete floor can be summarized in that the fiber pull-out resistance and the reaction force of the waterproof reinforcement immediately after cracking causes a reduction of the crack length $(l)$ from the rapid load transfer, and as a result, the fiber bridging zone $\left(l_{f}\right)$ is widely protected. Therefore, it is determined that the residual stress rises, maintains, and slows, as the resistance of the fiber bridging in the cracked section and the effect of the waterproofing reinforcement layer is combined.
\end{abstract}

Keywords: factory floor; fiber reinforce concrete; structural fibers; waterproof reinforcement; toughness; residual stress

\section{Introduction}

Due to the development of the industry, the increase in the distribution volume and production of various goods has resulted in the new construction, extensions of buildings and the continued renovation of industrial facilities (collectively called distribution centers and factories) [1-4]. The owners of such industrial facilities are required to complete the construction of durable buildings as soon as possible. In general, reducing the construction duration requires simplification and complexation of the main processes. Ground reinforcement in industrial facilities is one of the important processes for the initial shortening of the construction period. Depending on the site conditions, various required 
performances-such as damp proof property, waterproofness, chemical resistance, and chloride invasion resistance-are required [5-7]. Existing industrial facilities are mainly built in fill-up or coastal areas. In most industrial facilities, ground reinforcing gypsum or the cement replacement method is applied to prevent defects such as cracking and breakage caused by deflection of the floor slabs by fixed and moving loads [8,9]. Such alternatives do not take into account durability, such as chemical resistance and salt resistance. Therefore, the floor slab is continuously damaged [10-13]. Industrial facilities need to secure alternatives that satisfy various requirements based on the necessary performance by analyzing the ground environment before construction.

In specimens incorporating polyolefin fiber, there was a significant increase in fracture energy and ductility [14]. In particular, in the case of polyolefin fiber-reinforced concrete incorporating $10 \mathrm{~kg} / \mathrm{m}^{3}$, the tensile strength improved by almost $30 \%$. The process of transferring applied loads from the concrete matrix to the distributed fibers after the initial cracking tended to be quite different from that of the steel fiber-incorporated specimen. The shapes of the load-deflection curves were smooth and had characteristic linear trends during the post-cracking process. Two characteristic turning points showed in the minimum load after the first softening branch and the maximum remaining load for larger deformations. In order to increase the flexural toughness and durability (chemical and salt resistance) [15-24], it is necessary to apply the fiber reinforced concrete and the reinforcing materials to the lower surface of the concrete to evaluate the effects of the flexural performance [25-27].

The purpose of this study was to research the effects of reinforced layers (protective materials with waterproofing ability) on the flexural toughness of concrete. In addition, the experiment program consists of checking the residual stress $\left(R_{e 3}\right)$ according to the type of fiber mixing in the same conditions. The protective materials with waterproofing ability were installed in the concrete bottom during the mixing process, and the flexural strength test was carried out. When a crack occurs in concrete from the increasing load, the flexural toughness and the residual stress $\left(R_{e 3}\right)$ were checked to evaluate the performance of the applied protective materials and reinforced different fibers.

\section{Experimental Program}

The experiment is designed to evaluate the effects of the waterproof layer on the resistance of the crack growth due to the brittle fracture of the concrete during flexural load by casting the test specimen with four types of waterproof reinforcement under the concrete test specimen mixed with concrete reinforcing fibers.

\subsection{Materials}

\subsubsection{Concrete Reinforcing Fiber}

Fiber reinforcement for concrete, in general, is mixed with concrete to improve the mechanical properties, such as tensile strength, bending strength, impact resistance, crack restraint, and toughness [28-31]. In this study, the tested specimens were prepared using steel fiber and micro polypropylene fiber. The specifications of the material are shown in Table 1.

Table 1. Material property of reinforced fibers.

\begin{tabular}{|c|c|c|c|}
\hline Fiber Type & Materi & roperty & Reference \\
\hline Micro PP Fiber (MF) & $\begin{array}{l}\text { - } \quad \text { specific gravity: } 0.91 \\
\text { - } \quad \text { diameter: } 030 \mu \mathrm{m} \\
\text { - } \quad \text { modulus of elasticity: } 9.5 \mathrm{GPa}\end{array}$ & $\begin{array}{ll}\text { - } & \text { length: } 6 \mathrm{~mm} \\
\text { - } & \text { flash point: } 590{ }^{\circ} \mathrm{C} \\
\text { - } & \text { tensile strength: } 620 \mathrm{MPa}\end{array}$ & high acid, alkali and salt resistance \\
\hline
\end{tabular}




\subsubsection{Protective Materials}

The protective layers with waterproofing qualities used in this study were PE films (moisture-proof materials), Typar SF 65 (ground reinforcement materials) of Dupont, Bituthene 3000 (self-supporting sheet waterproofing materials), and Preprufe (pre-installed sheet waterproofing materials) of Grace. Specifications for the material are shown in Table 2.

Table 2. Material property of the water-resistant layer.

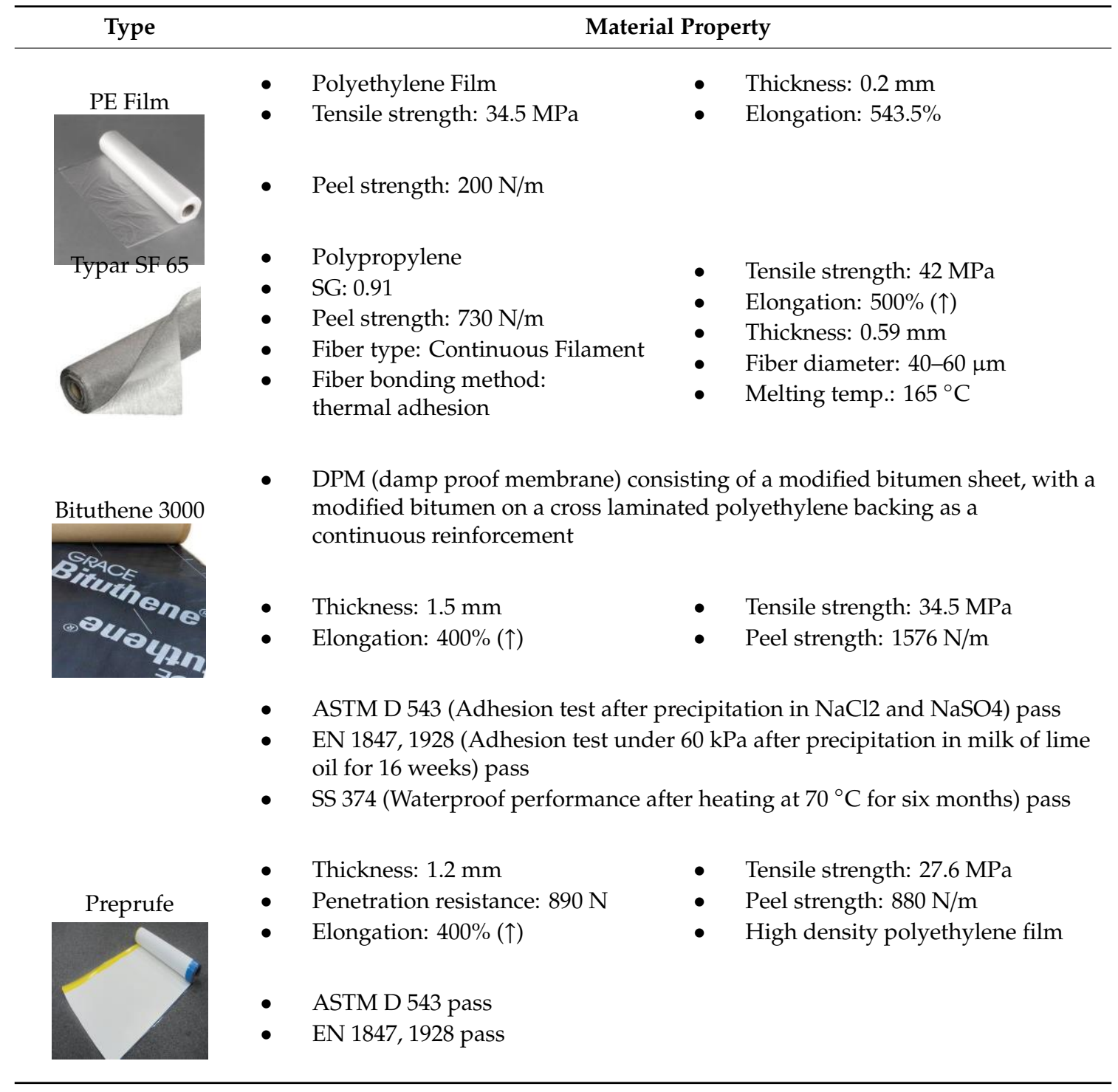

\subsubsection{Experimental Composition}

The combination of materials for concrete specimens with the waterproofing materials used in the study are shown in Table 3. 
Table 3. Composition of test specimens from protective waterproof materials.

\begin{tabular}{ccccc}
\hline Combination of Materials & PE FILM (PE) & $\begin{array}{c}\text { Typar SF 65 } \\
\text { (Typar) }\end{array}$ & $\begin{array}{c}\text { Bituthene 3000 } \\
\text { (Bituthene) }\end{array}$ & Preprufe \\
\hline Ordinary Plain Concrete (OPC) & OPC-PE & OPC-Typar & OPC-Bituthene & OPC-Preprufe \\
\hline Steel Fiber $20 \mathrm{~kg} / \mathrm{m}^{3}$ (SF 20) & SF20-PE & SF20-Typar & SF20-Bituthene & SF20-Bituthene \\
\hline Micro Fiber $1.0 \mathrm{~kg} / \mathrm{m}^{3}$ (MF 1.0) & MF1.0-PE & MF1.0-Typar & MF1.0-Bituthene & MF1.0-Bituthene \\
\hline Micro Fiber $2.8 \mathrm{~kg} / \mathrm{m}^{3}$ (MF 2.8) & MF2.8-PE & MF2.8-Typar & MF2.8-Bituthene & MF2.8-Bituthene \\
\hline
\end{tabular}

\subsection{Specimen Preparation}

\section{Mixing Proportion}

The concrete mixing ratio used in this study was designed based on the strength of a $30 \mathrm{MPa}$, $120 \mathrm{~mm}$ slump, which is actually applied to the site, and the mixing ratio is as follows in Table 4 .

Table 4. Mix proportion.

\begin{tabular}{cccccccccc}
\hline Type & $\begin{array}{c}\text { W/C } \\
(\mathbf{\%})\end{array}$ & S/a (\%) & $\begin{array}{c}\text { Water } \\
\left(\mathbf{k g} / \mathbf{m}^{3}\right)\end{array}$ & $\begin{array}{c}\text { Cement } \\
\left(\mathbf{k g} / \mathbf{m}^{3}\right)\end{array}$ & $\begin{array}{c}\text { FA } \\
\left(\mathbf{k g} / \mathbf{m}^{3}\right)\end{array}$ & $\begin{array}{c}\text { CA } \\
\left(\mathbf{k g} / \mathbf{m}^{3}\right)\end{array}$ & SP $(\mathbf{C} \times$ \%) & $\begin{array}{c}\text { Fiber } \\
(\%)\end{array}$ & Ref. \\
\hline OPC & 42.5 & 47.5 & 165 & 388 & 845 & 973 & 2.72 & - & $\begin{array}{c}\text { Steel } \\
\text { Fiber }\end{array}$ \\
\hline SF 20 & 42.5 & 47.5 & 165 & 388 & 845 & 973 & 2.72 & 0.84 & $\begin{array}{c}\text { Micro } \\
\text { Fiber }\end{array}$ \\
\hline $\begin{array}{c}\text { MF } \\
1.0\end{array}$ & 42.5 & 47.5 & 165 & 388 & 845 & 973 & 2.72 & 0.04 & $\begin{array}{c}\text { Micro } \\
\text { Fiber }\end{array}$ \\
\hline $\begin{array}{l}\text { MF } \\
2.8\end{array}$ & 42.5 & 47.5 & 165 & 388 & 845 & 973 & 2.72 & 0.12 & \\
\hline
\end{tabular}

\section{Test Methods}

\subsection{Test Specimen}

The slump test was based on the KS F 2402-07 [32] and an air volume test was conducted according to the KS F 2461-06 [33]. Compressive strength and flexural strength test specimens were casted according to the KS F 2403-14 [34]. The compressive test mold was filled with about 1/2 of fresh concrete and then compacted with each specimen. Each OPC, SF 20, MF 1.0, and MF 2.8 concrete was filled with the specimen mold. In the case of the bending test specimen, a $100 \times 400 \mathrm{~mm}$ waterproofing material and a protective material were installed on the side of the $100 \times 100 \times 400 \mathrm{~mm}$ test mold, and then finished by compacting it with fresh concrete mixed with OPC, SF 20, MF 1.0, and MF 2.8. The curing temperature of the poured compressive and bending test specimens were based on $20 \pm 3{ }^{\circ} \mathrm{C}$, demolded in the mold within $48 \mathrm{~h}$, and then cured in water for 28 days until the compressive strength test took place.

\subsection{Compressive Test}

The compressive strength test was based on KS F 2405-10 [35]. After grinding the upper and lower parts of the test specimen, it was placed in close contact with the pressure plate of the compressive test machine. At the beginning of the test, the load was applied at the same speed so as not to impact the placed specimen, and the speed of loading the specimen increased $0.6 \pm 0.4 \mathrm{MPa}$ until the concrete fractured.

\subsection{Crack Growth Resistance with Flexural Test}

The effect of reinforced layers with protective or waterproofing materials against the crack growth was tested with RILEM TC 162-TDF [36]. The deflection measuring device (LVDT) was installed on 
the lower part of the flexural strength test specimen (waterproof and protective material installation part) to fix it as shown in Figure 1. The flexural test was prepared by placing it on a four-point loading device with a structure that does not constrain the deformation of the specimen. A constant speed load was applied so as not to impact the specimen. The rate of loading was maintained until the maximum load was reached so that the rate of increase in the edge stress was $0.06 \pm 0.04 \mathrm{MPa}$ per second. The test was stopped when the deflection length of the specimen reached $3 \mathrm{~mm}$ or more. In addition, the toughness of the flexural strength test is graphed by the collected load-displacement data after the test type, and the load-displacement graph shows the toughness under the curve until the displacement becomes $1 / 150$ of the span. The most suitable design recommendation for designing industrial floors is the concrete industrial ground floor [37]. The use of the $R_{e 3}$ number for designing FRC floors is defined in the Japanese guideline JSCE SF-4 [38]. The $R_{e 3}$ number is the average of the residual stress and the flexural strength divided in percentage is shown in Figure 2.

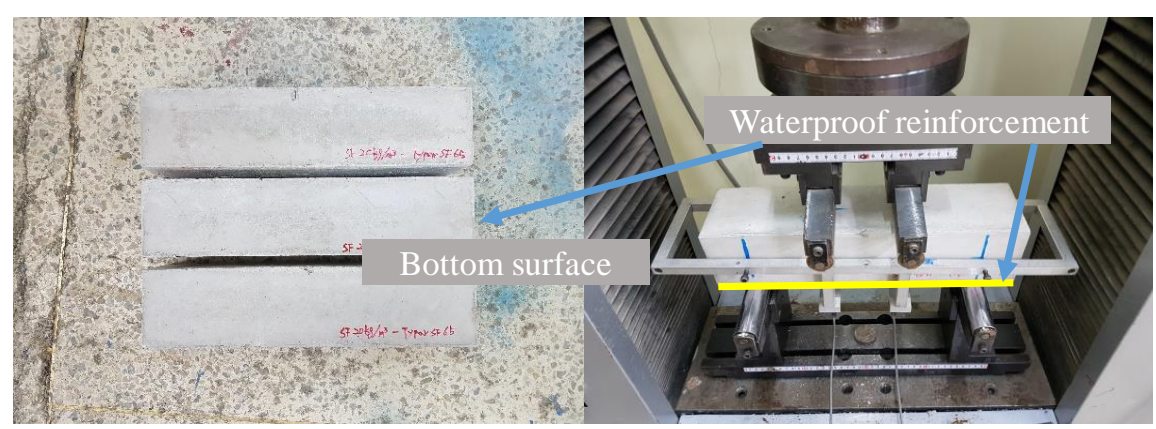

Figure 1. Flexural test setup with waterproof reinforcement.

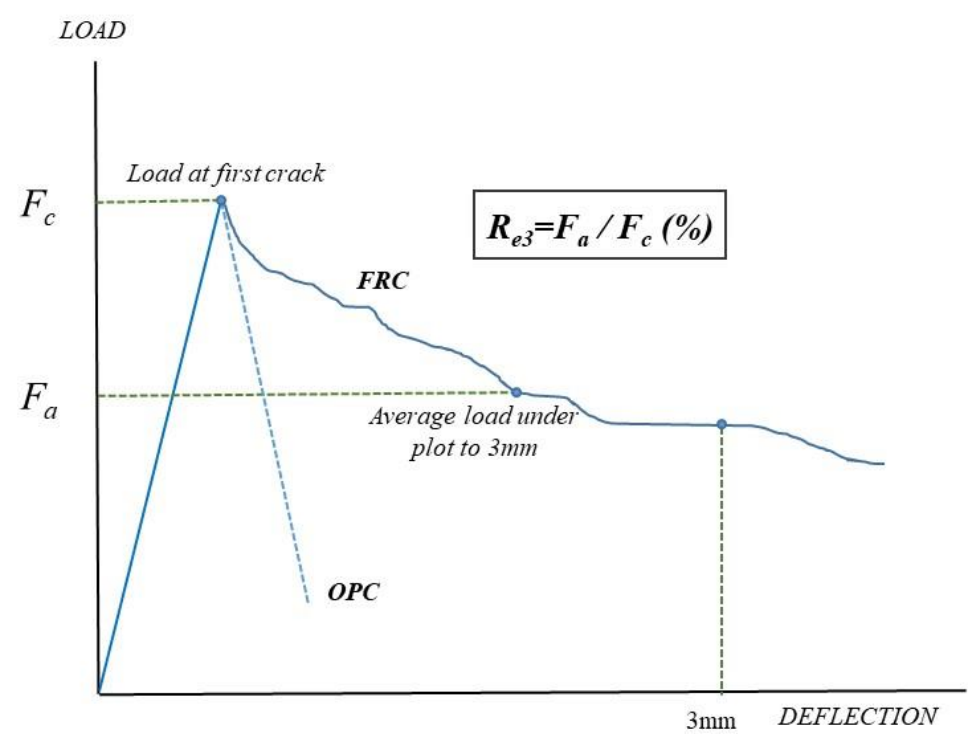

Figure 2. Calculation of residual stress (JSCE SF-4).

\section{Test Results}

\subsection{Compressive Strength}

The results of the compressive strength test for each specimen are shown in Table 5 and the compressive strengths due to the reinforcement of the fibers were all within the error range, indicating that there was no significant effect on the compressive strengths. The addition of different fiber shapes, lengths, diameter, and volume fraction is normally sensitive to the change of the consistency in fresh concrete conditions since homogenously distributed individual fibers among the interfaces between paste and aggregates greatly reduce flow ability and increase viscosity [39]. 
Table 5. The results of compressive strength test.

\begin{tabular}{cccccc}
\hline Type & OPC & $\begin{array}{c}\text { Steel Fiber } \\
\mathbf{2 0} \mathbf{~ k g} / \mathbf{m}^{\mathbf{3}}\end{array}$ & $\begin{array}{c}\text { Micro Fiber } \\
\mathbf{1 . 0} \mathbf{~} \mathbf{~ g} / \mathbf{m}^{\mathbf{3}}\end{array}$ & $\begin{array}{c}\text { Micro Fiber } \\
\mathbf{2 . 8} \mathbf{~ k g} / \mathbf{m}^{\mathbf{3}}\end{array}$ \\
\hline Compressive & 1 & 46.16 & 47.29 & 41.24 & 41.74 \\
strength (MPa) & 2 & 45.09 & 45.15 & 42.31 & 42.38 \\
Ave. & 3 & 43.70 & 43.83 & 39.98 & 42.31 \\
\hline
\end{tabular}

\subsection{Flexural Test Results}

Figure 3 shows the post-cracking resistance of the OPC for different waterproofing materials attached under concrete. The specimen (OPC-PE/) reinforced with polyethylene film indicates a sharp drop of applied load during the transitional period and represents the lowest residual load against the post-crack propagation. The specimen with OPC-Bituthene 3000 shows an almost similar tendency to the OPC-PE behavior. The specimens reinforced with Typar SF 65 and Preprufe delay crack propagation after the first crack initiation and show the highest residual load during crack development. The specimens reinforced with the addition of steel fiber $\left(20 \mathrm{~kg} / \mathrm{m}^{3}\right)$ as well as waterproofing reinforcement indicate an apparent improvement of post-cracking behaviors as shown in Figure 4. The addition of hooked steel fiber in the concrete significantly delayed crack propagation at the load transition zone and safely transferred the applied load to the waterproofing materials at which point they continuously resisted crack development. Among the types of waterproofing reinforcement materials, the specimen with SF 20-Typar SF 65 showed the best performance during post-cracking behaviors.

Figures 5 and 6 show the post-cracking behaviors of concrete reinforced with micro-fibers. The addition of micro-fiber with a dosage of $1.0 \mathrm{~kg} / \mathrm{m}^{3}$, as shown in Figure 5, indicates relatively lower residual loads than that of SF 20 and quite a similar tendency to that in Figure 3. The specimens reinforced with Typar SF 65 represented the highest residual loads during crack propagation. The load-displacement curves demonstrate some interesting results that with the help of both micro-fibers $\left(2.8 \mathrm{~kg} / \mathrm{m}^{3}\right)$ and waterproofing reinforcement significantly improved the post-cracking behavior while minimizing load reduction in the transition period for all types of waterproofing materials. Preprufe indicates an almost close post-cracking behavior compared to the Typar SF 65 . It can be summarized that different types of waterproofing materials with a combination of fiber types and fiber volume fractions help the apparent improvement of load dissipation after the first crack and the maintenance of relatively high residual loads against crack development.

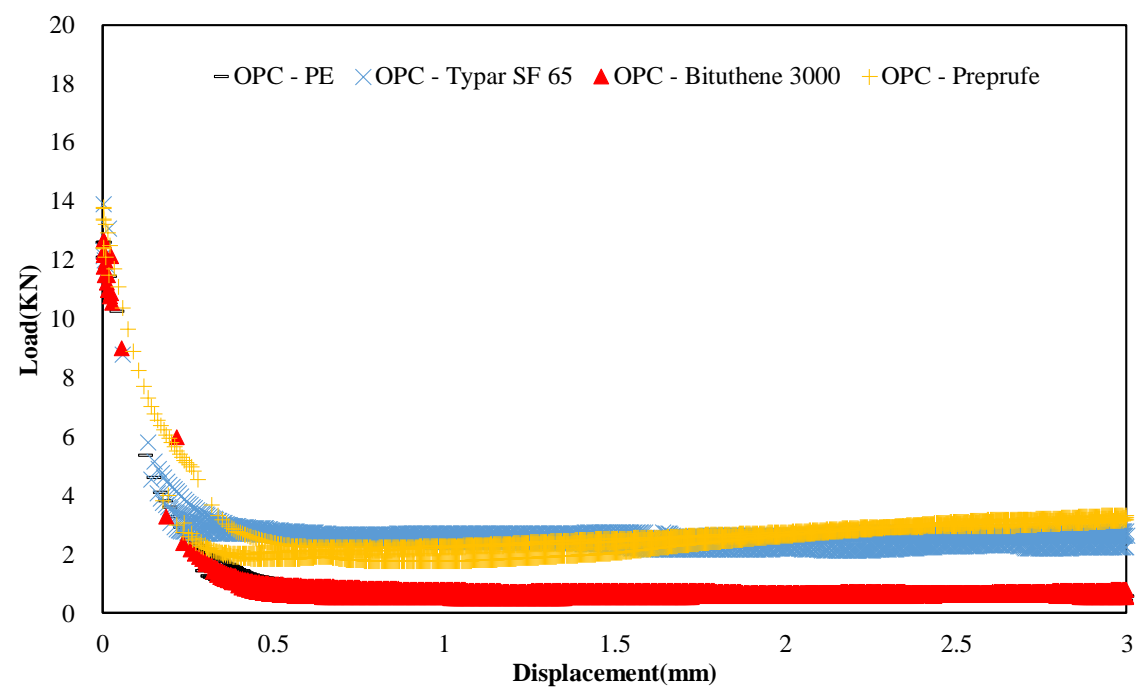

Figure 3. Load-displacement curve during crack propagation (OPC). 


\subsection{Flexural Test Performance}

Table 6 summarizes the flexural strength $\left(f_{r}\right)$, the toughness change for each section, and the residual stress $\left(R_{e 3}\right)$ for the flexural test performance using four types of concrete floor waterproofing reinforcement. In addition, according to the type of fiber reinforced inside the concrete as well as the fiber mixing ratio change, the correlation with the waterproofing reinforcement under concrete was clearly shown. Figure 7 shows the change in flexural strength due to the four types of waterproof reinforcement. Overall, the flexural strength due to the reinforcement of the waterproofing agent showed better strength than the OPC. Among the specimens reinforced with PE, the results of the fiber mixing showed an improvement in flexural strength in the order of SF20, MF1.0, and MF2.8. For the specimen reinforced with Typar, the flexural strength was greatly improved, but the effect on the change of fiber type and mixing ratio was found to be insignificant. In the case of the test specimens reinforced with Bituthene, the flexural strength was slightly lower compared to the results of the specimens reinforced with PE, but the tendency for the fiber type and mixing rate change was very similar. For the specimens reinforced with Preprufe, the changes in flexural strength due to SF20 and MF1.0 were insignificant, and the flexural strength of MF2.8 specimens was the best. As a result, it can be confirmed from the test results that specimens reinforced with the MF2.8 showed a very pronounced improvement in flexural strength due to four types of waterproof reinforcements.

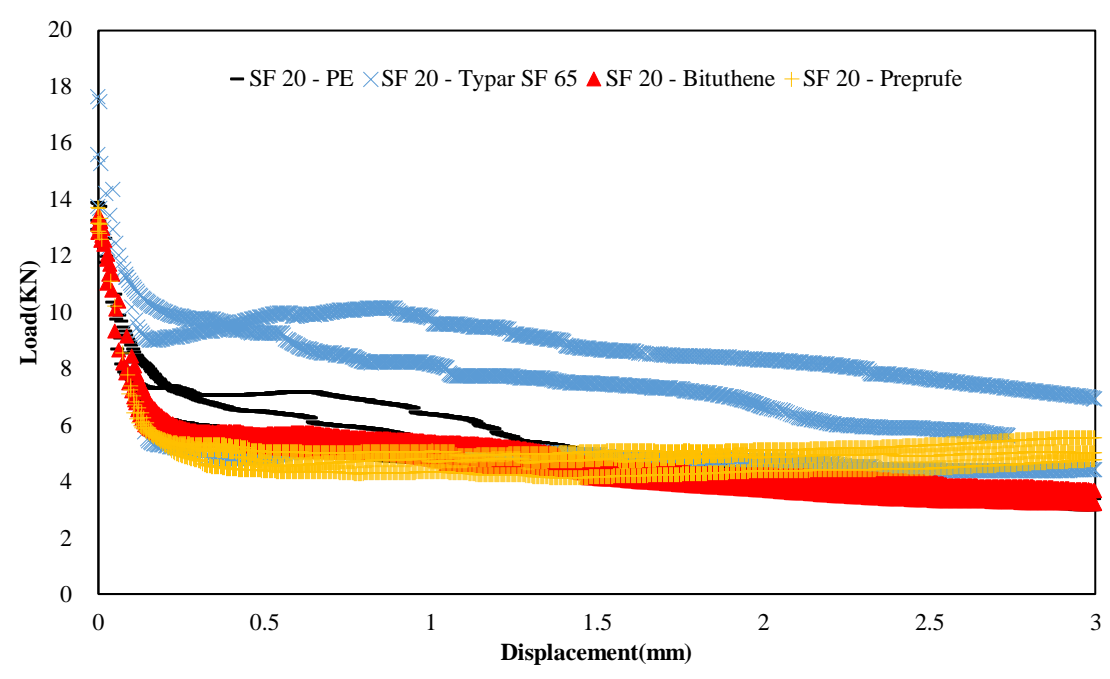

Figure 4. Load-displacement curve during crack propagation (SF 20).

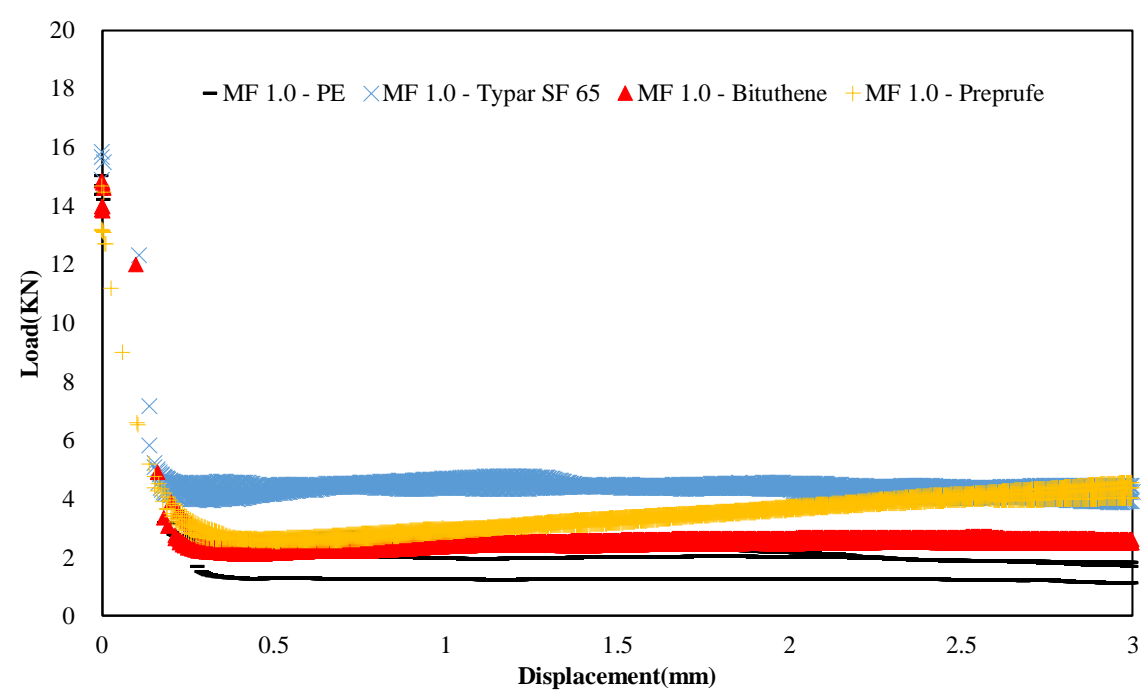

Figure 5. Load-displacement curve during crack propagation (MF 1.0). 
Figure 8 shows the toughness change for each section resulting from the waterproof reinforcement. The specimen without fiber reinforced inside the concrete showed a sharp decrease in toughness due to the brittle fracture after reaching the maximum load in the proportional limit $[29,39]$. On the other hand, for the reinforcement of the waterproof reinforcement material, the concrete matrix cracked after reaching the maximum load in the proportional limit and the waterproof reinforcement reinforced on the concrete surface suppressed cracking and loads instantly. It shows the improvement of toughness due to the continuous load-displacement curve by exerting resistance to crack development. In particular, the toughness of the specimen reinforced with Typar and Preprufe was noticeable against crack propagation.

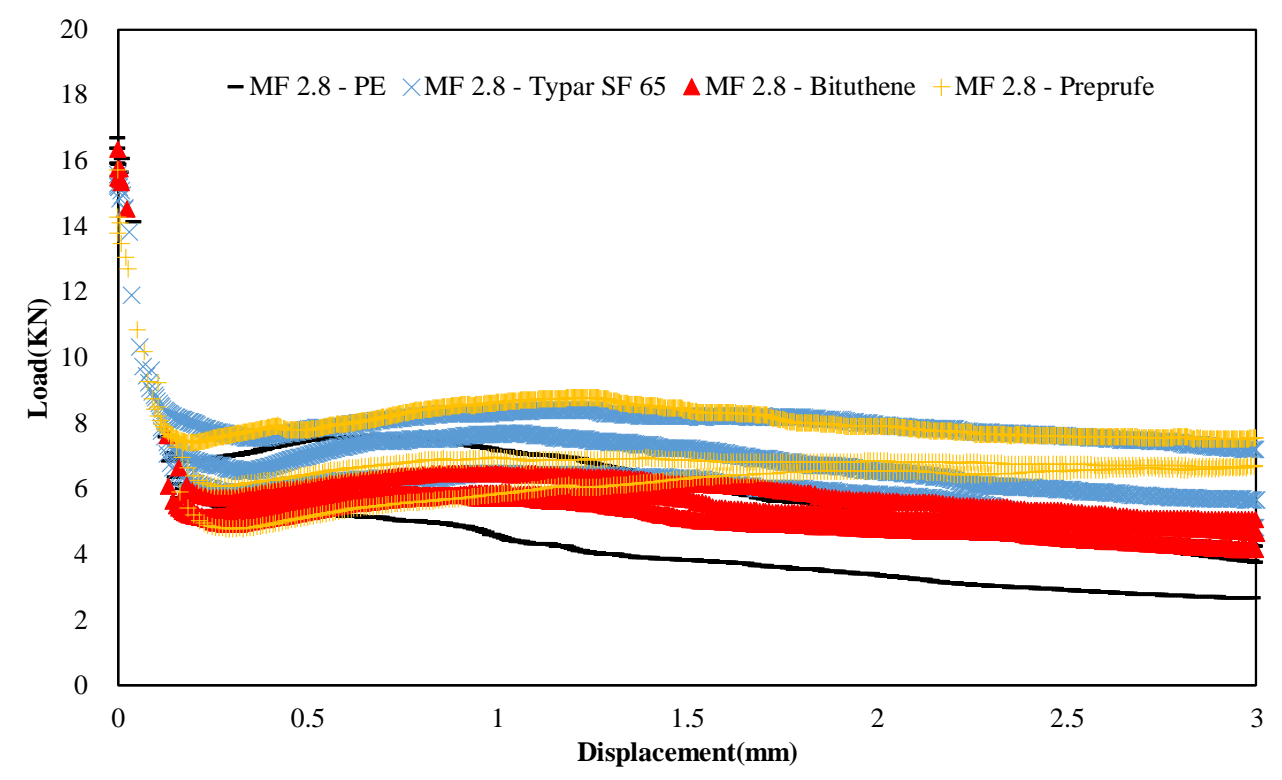

Figure 6. Load-displacement curve during crack propagation (MF 2.8).

Table 6. Summary of flexural test performance.

\begin{tabular}{|c|c|c|c|c|c|c|c|c|}
\hline \multirow{2}{*}{\multicolumn{2}{|c|}{ Type }} & \multicolumn{4}{|c|}{ Toughness (kN-mm) } & \multirow{2}{*}{$f_{c}^{\prime}(\mathrm{MPa})$} & \multirow{2}{*}{$f_{r}(\mathrm{MPa})$} & \multirow{2}{*}{$R_{e 3}(\%)$} \\
\hline & & 0-Peak & $0-0.5 \mathrm{~mm}$ & $0-2.0 \mathrm{~mm}$ & $0-3.0 \mathrm{~mm}$ & & & \\
\hline \multirow{5}{*}{ OPC } & N/A & - & - & - & - & 44.67 & 3.35 & - \\
\hline & PE & 0.364 & 2.445 & 3.374 & 3.880 & 44.98 & 3.71 & 5.67 \\
\hline & Typar & 0.564 & 2.721 & 6.515 & 9.027 & 44.98 & 3.84 & 20.43 \\
\hline & Bituthene & 0.248 & 2.536 & 3.534 & 4.182 & & 3.67 & 6.15 \\
\hline & Preprufe & 0.405 & 2.778 & 6.135 & 9.104 & & 3.96 & 19.86 \\
\hline \multirow{4}{*}{ SF20 } & PE & 0.304 & 3.897 & 11.756 & 15.392 & \multirow{4}{*}{45.44} & 4.01 & 37.96 \\
\hline & Typar & 0.613 & 4.649 & 15.713 & 21.361 & & 4.69 & 44.86 \\
\hline & Bituthene & 0.309 & 3.522 & 10.638 & 14.297 & & 3.93 & 35.07 \\
\hline & Preprufe & 0.457 & 3.316 & 10.338 & 15.249 & & 3.97 & 36.86 \\
\hline \multirow{4}{*}{ MF1.0 } & $\mathrm{PE}$ & 0.986 & 2.852 & 5.776 & 7.464 & \multirow{4}{*}{41.18} & 4.41 & 12.87 \\
\hline & Typar & 1.463 & 3.462 & 10.151 & 14.450 & & 4.64 & 28.47 \\
\hline & Bituthene & 0.277 & 2.755 & 6.541 & 9.007 & & 4.27 & 17.75 \\
\hline & Preprufe & 0.368 & 2.638 & 7.255 & 11.263 & & 4.10 & 25.19 \\
\hline \multirow{4}{*}{ MF2.8 } & $\mathrm{PE}$ & 1.318 & 4.157 & 12.408 & 16.193 & \multirow{4}{*}{42.14} & 4.97 & 20.44 \\
\hline & Typar & 0.394 & 4.128 & 14.991 & 21.309 & & 4.61 & 45.19 \\
\hline & Bituthene & 0.770 & 3.762 & 12.382 & 17.305 & & 4.76 & 35.41 \\
\hline & Preprufe & 0.818 & 3.937 & 14.543 & 21.519 & & 4.38 & 48.26 \\
\hline
\end{tabular}




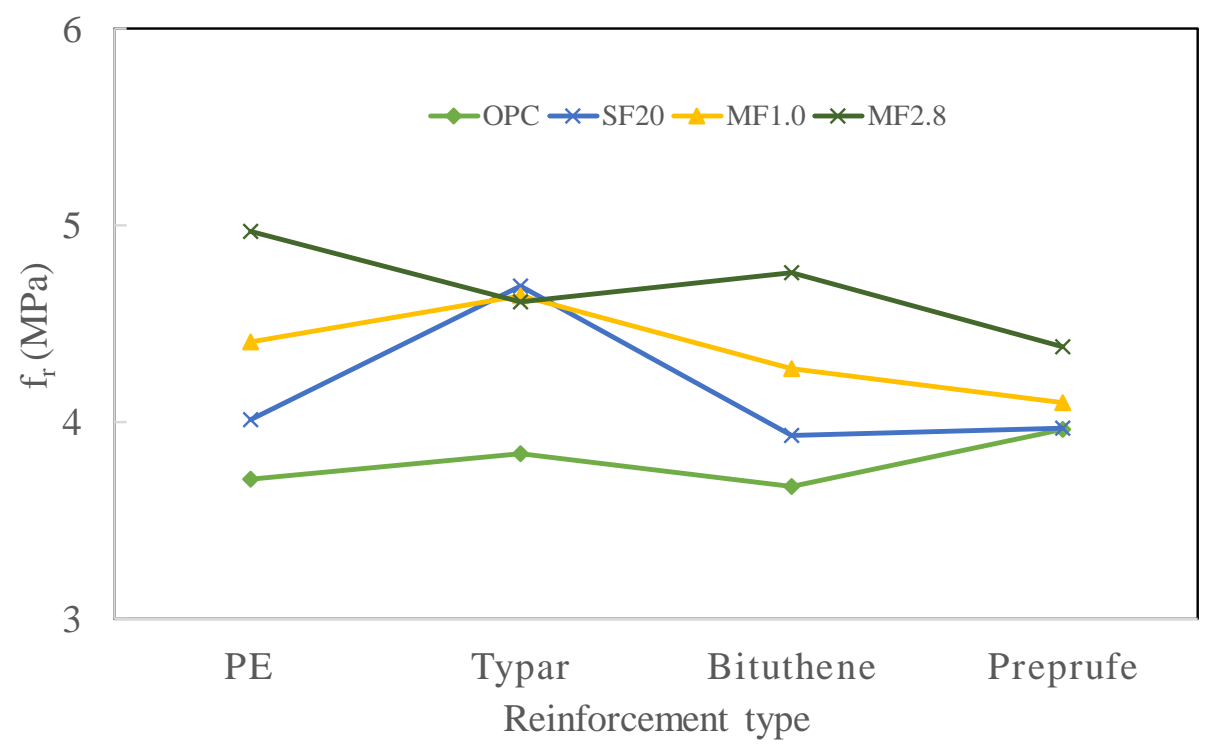

Figure 7. Flexural strength comparison with different types of waterproofing reinforcement.

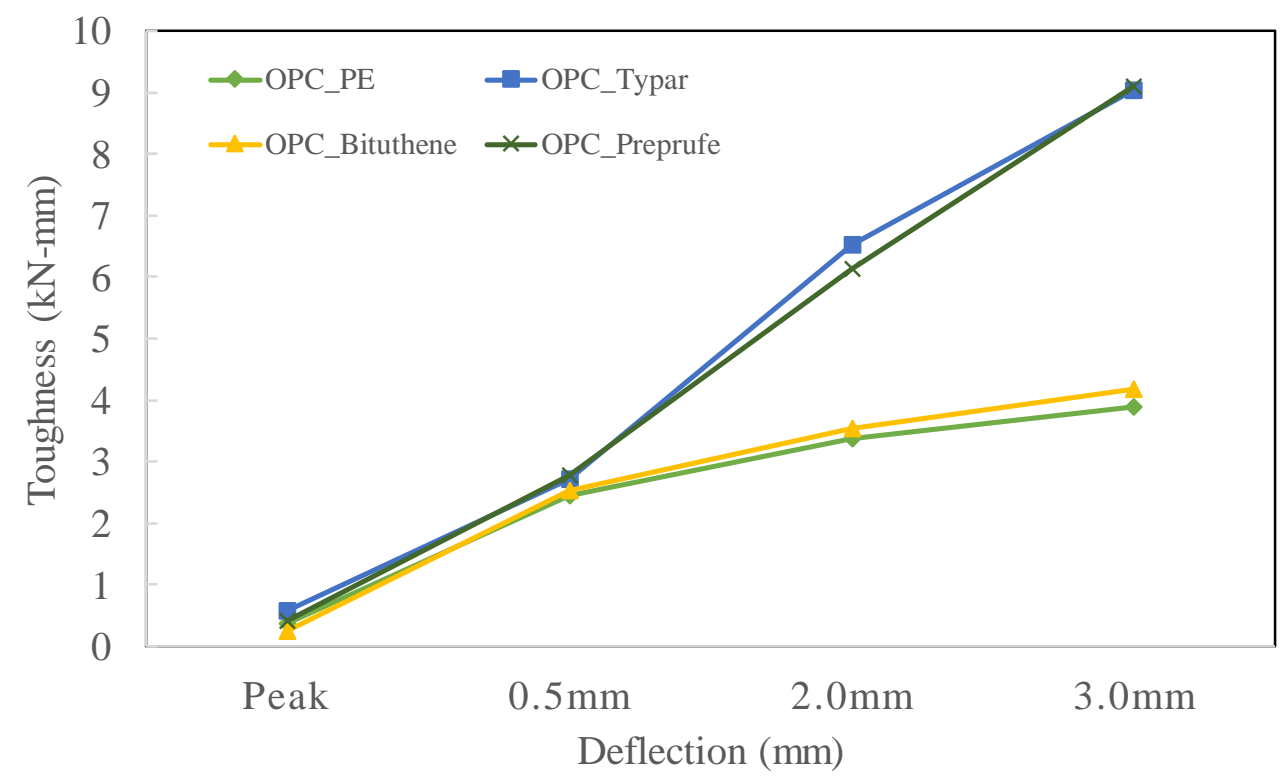

Figure 8. Toughness improvement with different types of waterproofing reinforcement.

Figure 9 shows the results comparing the toughness between the steel fiber reinforced specimen (SF20) and the OPC specimen. The performance of the waterproof reinforcement applied to the specimen reinforced with steel fiber shows a continuous toughness improvement as it passes the maximum load. The tendency to change by the type of waterproof reinforcement is similar, and it shows the best toughness increase in the test body reinforced with Typar. Figure 10 shows the results of comparing the toughness between the organic fiber-reinforced specimen (MF1.0) and the OPC specimen. The toughness at the maximum load showed that the specimens reinforced with PE and Typar were very large, but it can be seen from the $0.5 \mathrm{~mm}$ section that the tendency to change toughness is altered in a similar way to the other reinforcements. Since the concrete matrix has no significant effect on the increase in strength and toughness due to fiber reinforcement up to the fracture $[9,39]$, it is judged to be the result of the resistance ability of the waterproof reinforcement. Among the waterproof reinforcement materials, it showed that the most toughness increase in the test body was reinforced with Typar. Figure 11 shows the experimental results comparing the toughness between the test specimen (MF2.0) and the OPC specimen, which increased the mixing ratio of organic fibers. At the 
maximum load, it tends to be similar to the MF1.0, but the performance of the specimen reinforced with PE, Bituthene, and Preprufe was excellent. In the section of $0.5 \mathrm{~mm}$ or more, the tendency to increase in toughness due to the waterproof reinforcement was similar. It showed better toughness than the test specimen of MF1.0.

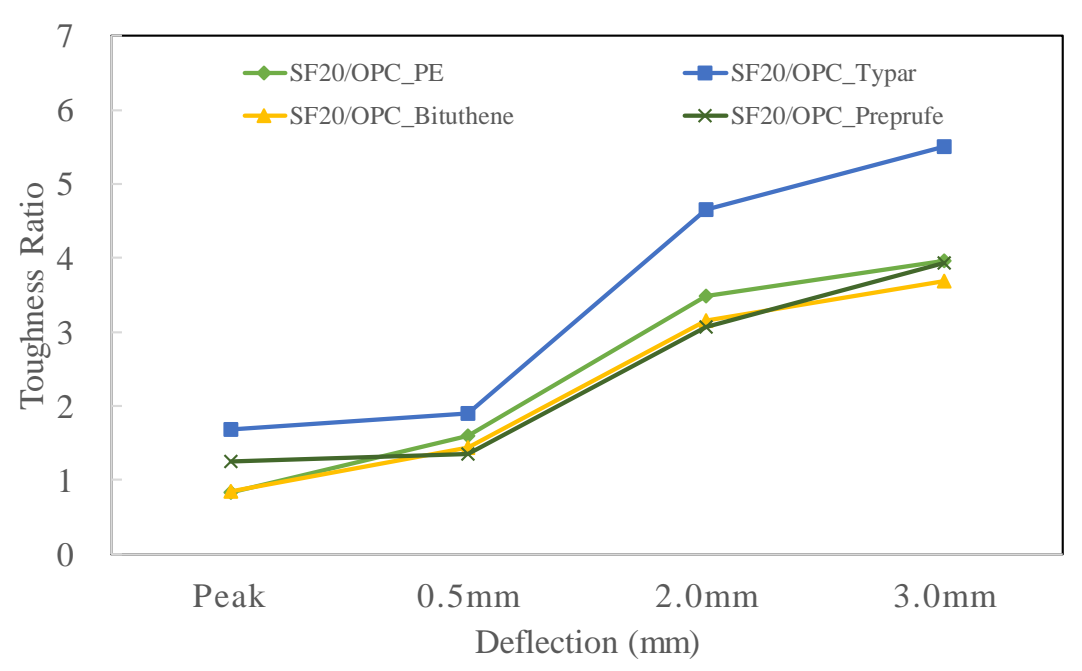

Figure 9. Toughness ratio between SF20 and OPC with waterproof reinforcement.

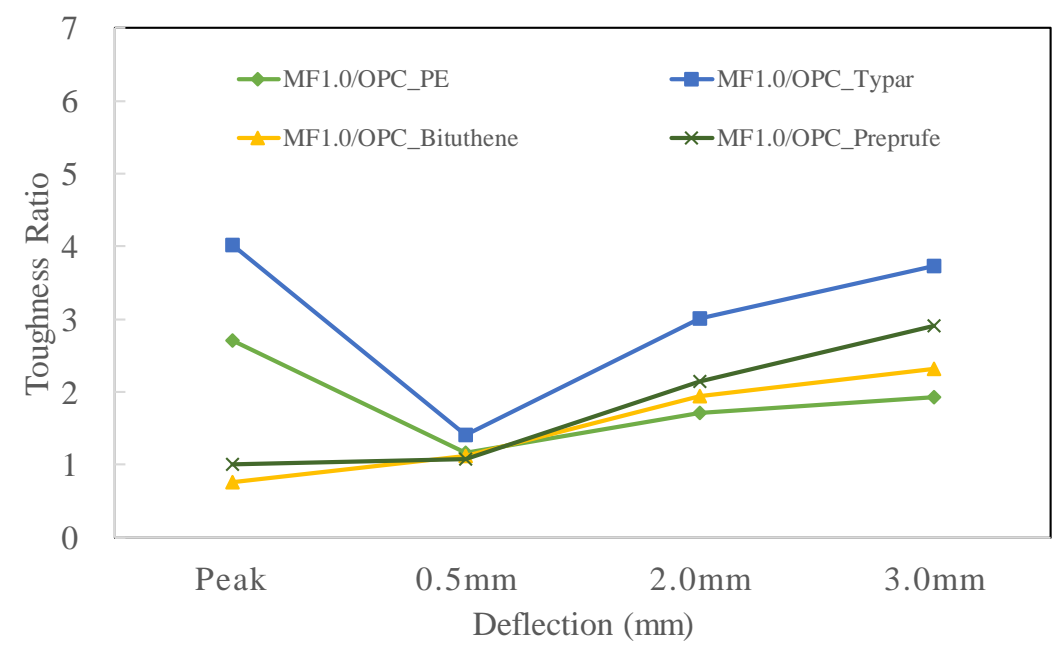

Figure 10. Toughness ratio between MF1.0 and OPC with waterproof reinforcement.

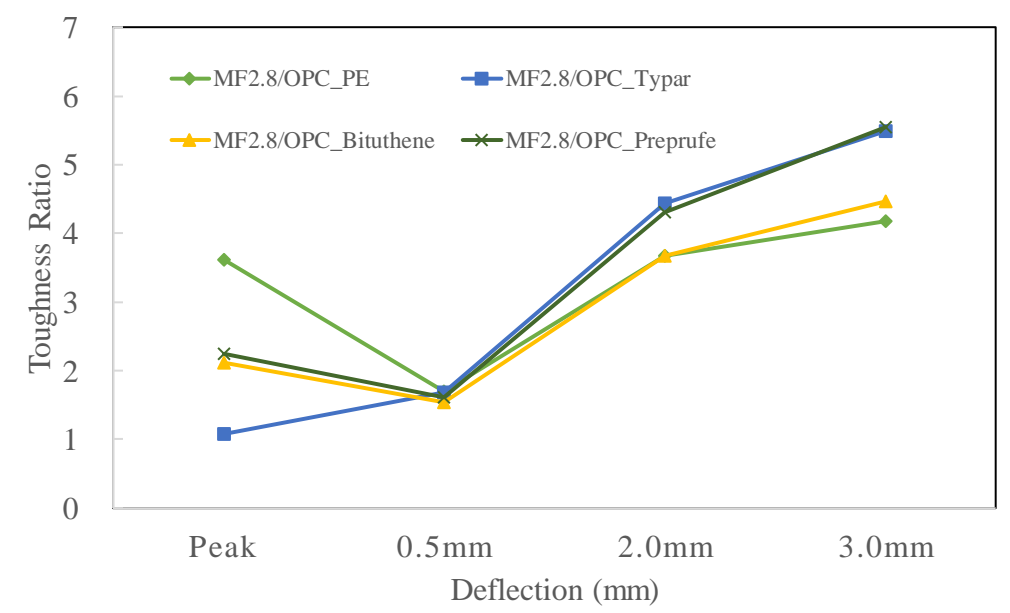

Figure 11. Toughness ratio between MF2.8 and OPC with waterproof reinforcement. 


\subsection{Residual Stress}

Figure 12 is a comparative analysis graph of the residual stress due to the influence of waterproof reinforcement in a test body mixed with OPC and fiber. In the case of the OPC specimens, the residual stress showed excellent results in the specimens reinforced with Typar and Preprufe. Compared to PE, Typar was found to have improved residual stress values of about $260 \%$ and Preprufe of about $250 \%$, even after concrete cracking. In particular, Typar and Preprufe reinforcements were found to have excellent residual stress in all test specimens containing fibers. As a result of the comparison between the steel fiber-incorporated test specimen (SF20) and OPC, the PE reinforcement was 6.7 times, Typar 7.9 times, Bituthene 6.2 times, and Preprufe 6.5 times. As a result of the comparison between the test sample (MF1.0) incorporating organic fiber and OPC, the PE reinforcement material was 2.3 times, Typar 5 times, Bituthene 3.1 times, and Preprufe 4.4 times. The comparison results of the organic fiber mixing rate (MF2.8) and OPC showed that the PE reinforcement was 3.6 times, Typar was 8 times, Bituthene was 6.2 times, and Preprufe was 8.5 times. In summary, the improvement of residual stress due to fiber mixing showed excellent results in all waterproof reinforcements in the test body (SF20) incorporating steel fibers. In particular, the best results were obtained in the steel fiber reinforced concrete specimens reinforced with Typar. In the case of the organic fiber, MF2.8 showed excellent results and showed a tendency almost equal to the SF20. The best crack resistance in the organic fiber reinforced concrete combined with Typar and Preprufe was confirmed.

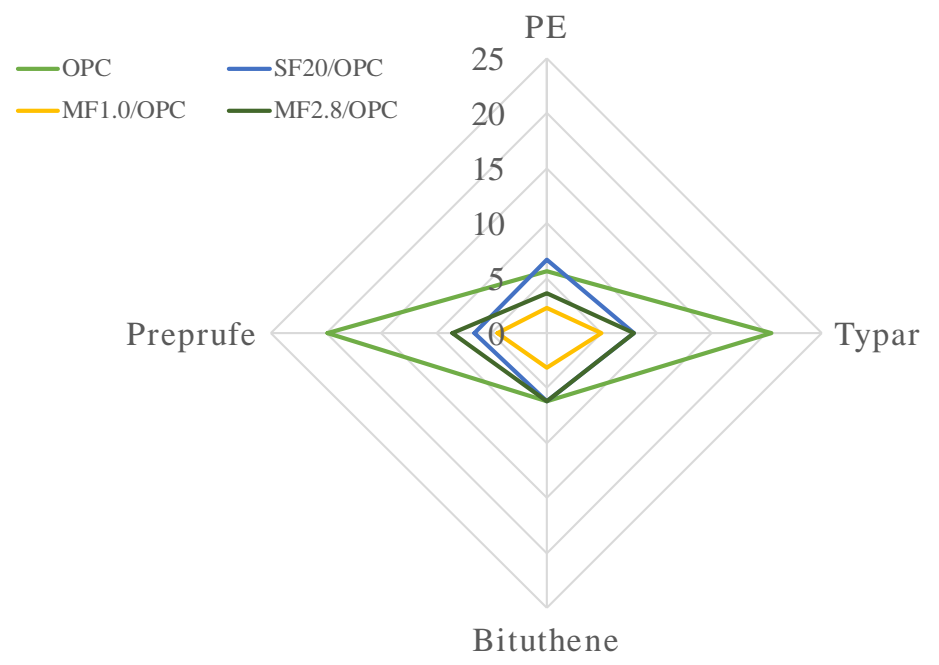

Figure 12. Comparison for residual stress between fiber addition and OPC.

\section{Resistance Ability of Waterproof Reinforcement for Flexural Failure}

In Figure 13, the changes in toughness and residual stress due to the mixing of waterproof reinforcement and internal fibers on the concrete floor surface are plotted and summarized. When fiber is incorporated into concrete, many researchers have found that the toughness due to fiber bridging occurs as the load transfers to the fiber after cracking the concrete matrix [39-42]. Toughness is normally determined by factors such as fiber type, mixing ratio, aspect ratio, and tensile strength. In previous test results, the waterproof reinforcement showed relatively good load resistance ability in the test specimen reinforced with a concrete floor with Typar and Preprufe. In particular, the load resistance capability due to the fiber addition is significantly improved. Excellent toughness was improved in all waterproof reinforcement materials, and it was shown that both an excellent toughness increase and residual stress were maintained in the test specimen reinforced with steel fiber mixing and Typar reinforcement. The toughness and residual stress ability were excellent in the test specimens reinforced with Typar and Preprufe, regardless of the mixing ratio, even in the specimens incorporating organic fibers. Figure 14 is a schematic diagram of the load transfer mechanism after the cracking of the concrete matrix. Due to the continuous load, the crack resistance capability is first applied to the fiber and 
waterproof reinforcement after the concrete matrix crack. The instantaneous load reduction depends on the pulling resistance of the fiber and the material properties of the waterproof reinforcement, so it is judged that the CMOD and crack length $(l)$ are reduced and the fiber bridging zone $\left(l_{f}\right)$ remains relatively large $[39,40,43]$. As a result, it is judged to have a tendency to increase, maintain, and slow the residual stress for a long period of time due to the continuous pulling-out resistance of the fiber and the load-resistance ability (reaction force) of the waterproof reinforcement during the continuous transfer process of the load.

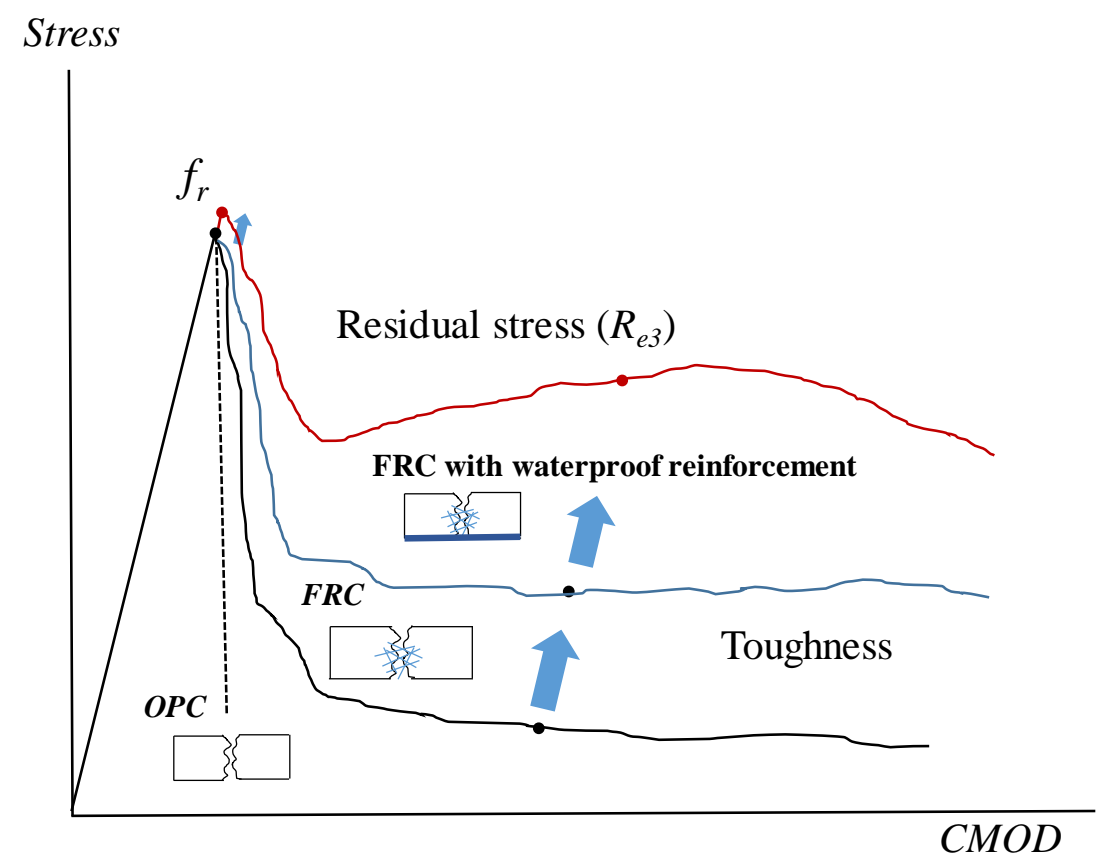

Figure 13. Comparison for residual stress between fiber addition and OPC.

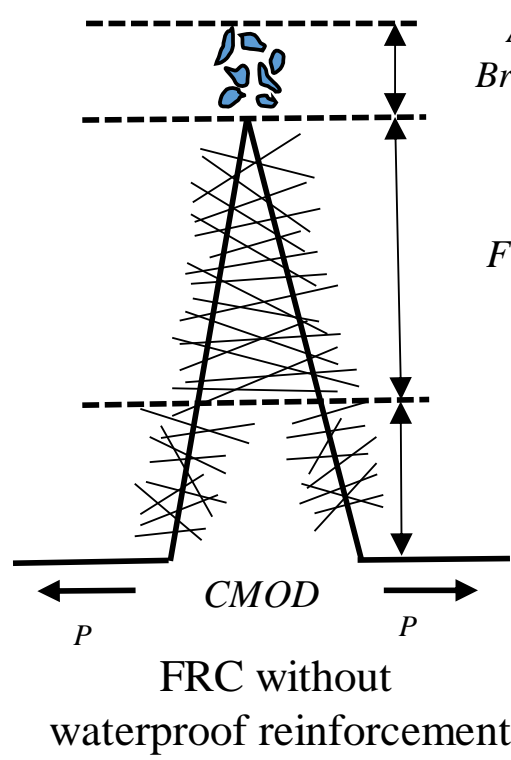

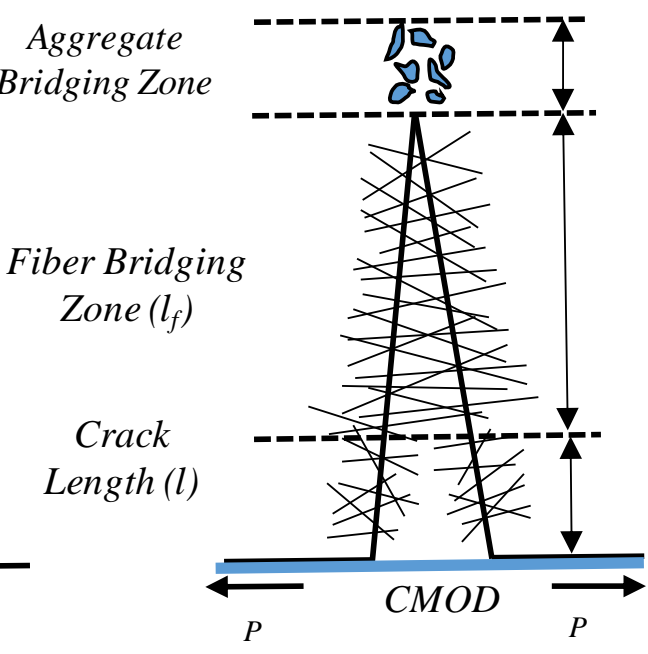

FRC with

waterproof reinforcement

Figure 14. Schematic diagram of the effects of waterproof reinforcement on the fiber bridging zone.

\section{Conclusions}

In this study, four types of reinforcing materials with waterproof performance were fixed to the lower part of the concrete layer and steel fibers and organic fibers were applied to the concrete to protect it from cracks and damages of the concrete layer due to any deflection of the floor slab against 
fixed and moving loads at the factory floor. Incorporation was performed to evaluate the change in flexural strength, analysis of the load transfer mechanism during cracking of the concrete matrix, and the ability to maintain residual stress during the cracking process. The research results from the experimental results and analysis are summarized as follows:

1. The flexural strength of four types of waterproof reinforcement was improved by about $10-48 \%$. The flexural strength improvement of the test specimen reinforced with Typar and Prepurf was the best among all the specimens, and the increase in flexural strength due to the combination of the steel fiber (SF20) and organic fiber (MF2.8) and the reinforcing material was apparent. In particular, the SF20 + Typar and MF2.8 + Preprufe test specimens showed results of improved flexural strength of 45 and $48 \%$, respectively.

2. The change in toughness showed a marked improvement in all specimens due to the combination of fiber and waterproof reinforcement. After the concrete matrix cracking, the toughness due to the fiber pull-out resistance and the increase in the reaction force of waterproof reinforcement showed a continuous increase in toughness in the specimen reinforced with the steel fiber. Toughness due to organic fiber mixing showed stable toughness improvements after an unstable toughness change from a maximum load to $0.5 \mathrm{~mm}$. The test specimen reinforced with Typar showed the best crack resistance regardless of fiber type.

3. The crack transfer mechanism in the concrete floor layer due to fiber mixing and water-reinforcing reinforcement decreases the crack length $(l)$ as the load due to the fiber pull-out resistance and the reaction force generation of the reinforcing material decreases immediately after the cracking of the concrete matrix, thereby protecting the fiber bridging zone $\left(l_{f}\right)$. Afterwards, it is judged that the residual stress rises, maintains, and slows, as the resistance of the fiber pullout and the effect of the reinforcement is combined.

Author Contributions: B.K., S.-K.O., and J.-I.K. designed the experiment and analyzed the experimental data; M.-H.G. and J.-Y.S. performed the experiment. All authors have read and agreed to the published version of the manuscript.

Funding: This study was financially supported by the Seoul National University of Science and Technology.

Conflicts of Interest: The authors declare no conflict of interest.

\section{Abbreviations and Acronyms}

The following abbreviations are used in this manuscript:

$\begin{array}{ll}\text { OPC } & \text { Ordinary Plain Concrete } \\ \text { FA } & \text { Fine Aggregate } \\ \text { CA } & \text { Coarse Aggregate } \\ \text { SP } & \text { Super Plasticizer } \\ \text { SF } & 20 \text { Steel Fiber } 20 \mathrm{~kg} / \mathrm{m}^{3} \\ \text { MF } & 1.0 \text { Micro Fiber } 1 \mathrm{~kg} / \mathrm{m}^{3} \\ \text { MF } & 2.8 \text { Micro Fiber } 2.8 \mathrm{~kg} / \mathrm{m}^{3} \\ R_{e 3} & \text { Residual Stress } \\ L_{f} & \text { Fiber Bridging Zone } \\ \text { LVDT } & \text { Linear Variable Differential Transformer } \\ \text { PE } & \text { Polyethylene } \\ f_{r} & \text { Flexural Strength } \\ \text { CMOD } & \text { Crack Mouth Opening Displacement }\end{array}$

\section{References}

1. Meyer, C. The greening of the concrete industry. Cem. Concr. Compos. 2009, 31, 601-605. [CrossRef]

2. Mehta, P.K. Global concrete industry sustainability. Concr. Int. 2009, 31, 45-48. 
3. Sealey, B.J.; Philips, P.S.; Hill, G.J. Waste management issues for the UK ready-mixed concrete industry. Resour. Conserv. Recycl. 2001, 32, 321-331. [CrossRef]

4. Holton, I.; Glass, J.; Price, A.D.F. Managing for sustainability: Findings from four company case studies in the UK precast concrete industry. J. Clean. Prod. 2010, 18, 152-160. [CrossRef]

5. Ahn, D.S.; Oh, K.H.; Park, J.S.; Oh, S.-K. Viscosity and Waterproofing Performance Evaluation of Synthetic Polymerized Rubber Gel (SPRG) after Screw Mixing. Appl. Sci. 2018, 8, 1989. [CrossRef]

6. Oh, S.-K.; Shim, J.-S. Maintenance for Leakage due to Cracking in Concrete Structures-Guidelines for Repair of Water-Leakage Cracks in Concrete Structures. J. Korea Concr. Inst. 2011, 23, 47-52.

7. Chen, X.; Zhu, Y.; Cai, D.; Xu, G.; Dong, T. Investigation on Interface Damage between Cement Concrete Base Plate and Asphalt Concrete Waterproofing Layer under Temperature Load in Ballastless Track. Appl. Sci. 2020, 10, 2654. [CrossRef]

8. Hoła, J.; Sadowski, Ł.; Nowacki, A. Analysis of the causes of cracks in marble slabs in a large-surface floor of a representative commercial facility. Eng. Fail. Anal. 2019, 97, 1-9. [CrossRef]

9. Mehta, P.K.; Monteiro, P.J.M. Concrete: Microstructure, Properties, and Materials, 3rd ed.; McGraw-Hill: New York, NY, USA, 2006.

10. Ismail, M.; Ohtsu, M. Corrosion rate of ordinary and high-performance concrete subjected to chloride attack by AC impedance spectroscopy. Constr. Build. Mater. 2006, 20, 458-469. [CrossRef]

11. Glass, G.K.; Buenfeld, N.R. The influence of chloride binding on the chloride induced corrosion risk in reinforced concrete. Corros. Sci. 2000, 42, 329-344. [CrossRef]

12. Jensen, O.M.; Hansen, P.F.; Coats, A.M.; Glasser, F.P. Chloride ingress in cement paste and mortar. Cem. Concr. Res. 1999, 29, 1497-1504. [CrossRef]

13. Sakai, Y. Relationship between pore structure and chloride diffusion in cementitious materials. Constr. Build. Mater. 2019, 229, 116868. [CrossRef]

14. Alberti, M.G.; Enfedaque, A.; Gálvez, J.C. On the mechanical properties and fracture behavior of polyefin fiber-reinforced self-compacting concrete. Constr. Build. Mater. 2014, 55, 274-288. [CrossRef]

15. Lee, J.; Lee, T. Influences of Chemical Composition and Fineness on the Development of Concrete Strength by Curing Conditions. Materials 2019, 12, 4061. [CrossRef] [PubMed]

16. Kumar, M.P.; Mini, K.M.; Rangarajan, M. Ultrafine GGBS and calcium nitrate as concrete admixtures for improved mechanical properties and corrosion resistance. Constr. Build. Mater. 2018, 182, 249-257. [CrossRef]

17. Luo, R.; Cai, Y.; Wang, C.; Huang, X. Study of chloride binding and diffusion in GGBS concrete. Cem. Concr. Res. 2003, 33, 1-7. [CrossRef]

18. Mohan, A.; Mini, K.M. Strength and durability studies of SCC incorporating silica fume and ultra fine GGBS. Constr. Build. Mater. 2018, 171,919-928. [CrossRef]

19. Özbay, E.; Erdemir, M.; Durmuş, H.I. Utilization and efficiency of ground granulated blast furnace slag on concrete properties-A review. Constr. Build. Mater. 2016, 105, 423-434. [CrossRef]

20. Chunxiang, Q.; Patnaikuni, I. Properties of high-strength steel fiber-reinforced concrete beams in bending. Cem. Concr. Compos. 1999, 21, 73-81. [CrossRef]

21. Zollo, R.F. Fiber-refinforced concrete: An overview after 30 years of development. Cem. Concr. Compos. 1997, 19, 107-122. [CrossRef]

22. Sovják, R.; Máca, P.; Imlauf, T. Effect of fibere length on the fracture energy of UHPFRC. Procedia Eng. 2017, 193, 74-79. [CrossRef]

23. Tang, K.; Wilkinson, S. Corrosion resistance of electrified railway tunnels made of steel fibre reinforced concrete. Constr. Build. Mater. 2020, 230, 117006. [CrossRef]

24. Rashid, M.U. Experimental investigation on durability characteristics of steel and polypropylene fiber reinforced concrete exposed to natural weathering action. Constr. Build. Mater. 2020, 250, 118910. [CrossRef]

25. Ede, A.N.; Ige, A. Optimal polypropylene fibre content for improved compressive and flexural strength of concrete. IOSR J. Mech. Civ. Eng. (IOSR-JMCE) 2014, 11, 129-135.

26. Nehme, S.G.; László, R.; Mir, A.E. Mechanical Performance of Steel Fiber Reinforced Self-compacting Concrete in Panels. Procedia Eng. 2017, 196, 90-96. [CrossRef]

27. Hannant, P.J. Fibre Cements and Fibre Concretes; John Wiley: New York, NY, USA, 1978.

28. Banthia, N.; Zanotti, C.; Sappakittipakorn, M. Sustainable fiber reinforced concrete for repair applications. Constr. Build. Mater. 2014, 67, 405-412. [CrossRef] 
29. Han, Y.-J.; Oh, S.-K.; Kim, B. Effect of Load Transfer Section to Toughness for Steel Fiber-Reinforced Concrete. Appl. Sci. 2017, 7, 549. [CrossRef]

30. Kim, B.-I.; Han, Y.-J. Flexural Performance of Transparent Plastic Bar Reinforced Concrete. Appl. Sci. 2018, 8, 325. [CrossRef]

31. Zhang, S.; Zhang, C. Investigation on the relationship between the steel fibre distribution and the post-cracking behavior of SFRC. Constr. Build. Mater. 2019, 200, 539-550. [CrossRef]

32. KS F 2402-07. Slump Test Method of Concrete; Korea Industrial Standards: Seoul, Korea, 2007.

33. KS F 2461-06. Air Volume Test Method of Fresh Concrete by Pressure Method; Korea Industrial Standards: Seoul, Korea, 2006.

34. KS F 2403-14. Method of Fabricating Test Pieces for Concrete Strength Test; Korea Industrial Standards: Seoul, Korea, 2014.

35. KS F 2405-10. Test Method of Concrete Compressive Strength; Korea Industrial Standards: Seoul, Korea, 2010.

36. RILEM TC 162-TDF. Test and design methods for steel fiber reinforced concrete: Bending test. Mater. Struct. 2002, 35, 262-278. [CrossRef]

37. The Concrete Society. Concrete Industrial Ground Floors: A Guide to Their Design and Construction; TR 34 Third Edition; The Concrete Society: Camberley, UK, 2003.

38. JSCE-SF4. Methods of Tests for Flexural Toughness of Steel Fiber Reinforced Concrete; Japanese Society of Civil Engineers: Tokyo, Japan, 1985.

39. Beaudoin, J.J. Handbook of Fiber-Reinforced Concrete: Principles, Properties, Developments and Applications; Noyes: Park Ridge, NJ, USA, 1990; pp. 1-41.

40. Ding, C.; Guo, L.; Chen, B. Orientation distribution of polyvinyl alcohol fibers and its influence on bridging capacity and mechanical performances for high ductility cementitious composites. Constr. Build. Mater. 2020, 247, 118491. [CrossRef]

41. Lu, C.; Li, V.C.; Leung, C.K.Y. Flaw characterization and correlation with cracking strength in Engineered Cementitious Composites (ECC). Cem. Concr. Res. 2018, 107, 64-74. [CrossRef]

42. Lu, C.; Yu, J.; Leung, C.K. Tensile performance and impact resistance of strain hardening cementitious composites (SHCC) with recycled fibers. Constr. Build. Mater. 2018, 171, 566-576. [CrossRef]

43. Wecharatana, M.; Shah, S.P. Experimental Methods to Determine Fracture Parameters for Concrete; Technological Institute. Northwestern University: Evanston, IL, USA, 1982; p. 18. 